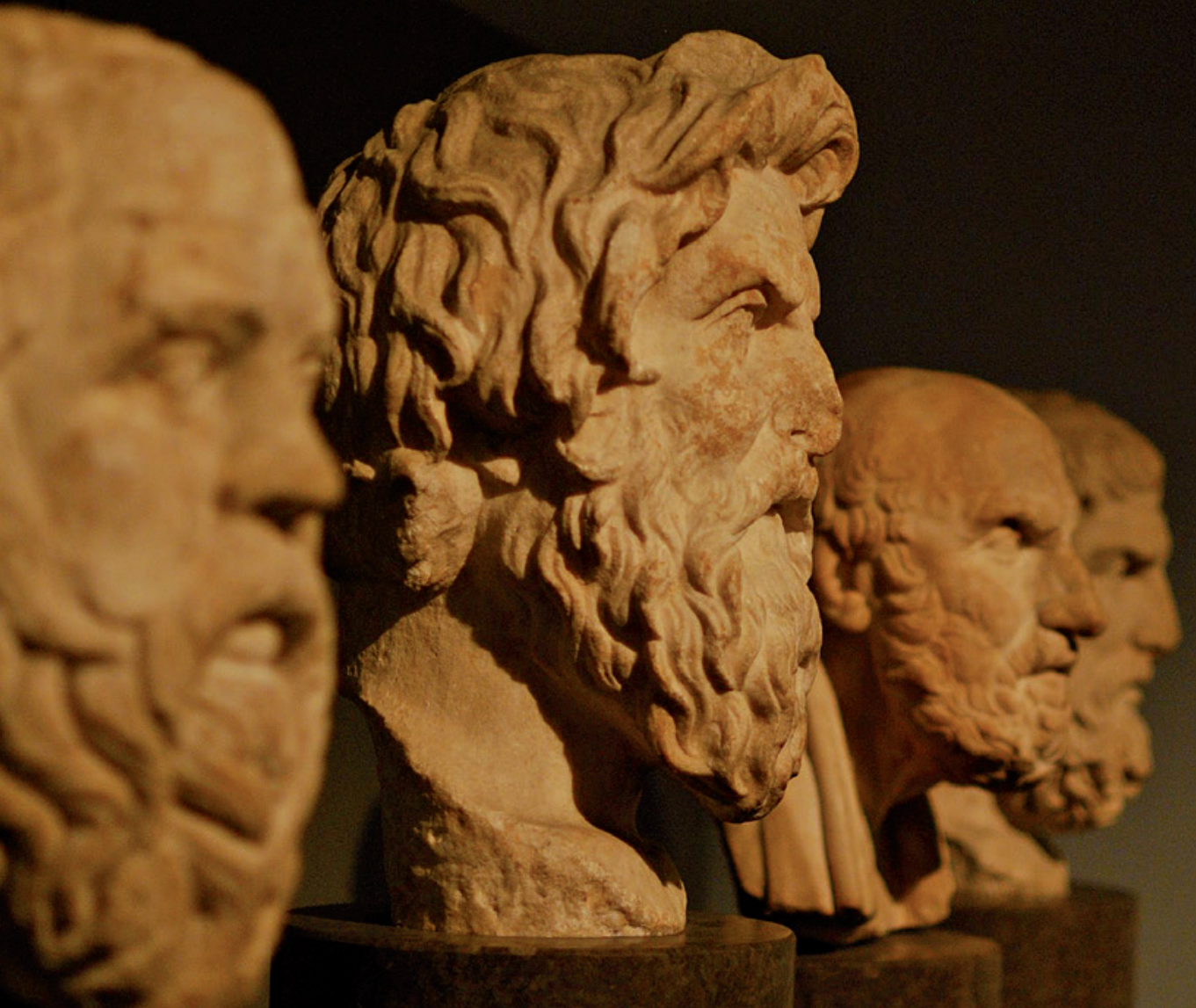

P.A. Meijer

\title{
A New Perspective on Antisthenes
}

\section{Logos, Predicate and Ethics in his Philosophy}


A New Perspective on Antisthenes 



\title{
A New Perspective on Antisthenes
}

Logos, Predicate and Ethics in his Philosophy

\author{
P.A. Meijer
}


Cover illustration: Sokrates, Antisthenes, Chrysippos and Epikouros (from left to right) Source: Wikimedia Commons / Matt Neale

Cover design: Coördesign, Leiden

Lay-out: Crius Group, Hulshout

Amsterdam University Press English-language titles are distributed in the US and Canada by the University of Chicago Press.

$\begin{array}{ll}\text { ISBN } & 9789462982987 \\ \text { e-ISBN } & 9789048532957 \text { (pdf) } \\ \text { DOI } & 10.5117 / 9789089646026 \\ \text { NUR } & 683 / 73^{2}\end{array}$

(C) P.A. Meijer / Amsterdam University Press B.V., Amsterdam 2017

All rights reserved. Without limiting the rights under copyright reserved above, no part of this book may be reproduced, stored in or introduced into a retrieval system, or transmitted, in any form or by any means (electronic, mechanical, photocopying, recording or otherwise) without the written permission of both the copyright owner and the author of the book. 
To Els,

for her support, tenderness and love 



\section{Contents}

Preface

Abbreviations

Primary sources - editions used

Introduction $\quad 21$

$1 \quad$ Antisthenes' status $\quad 21$

2 The importance of Antisthenes' philosophical views 24

\section{PART I LOGOS AND PREDICATE}

Chapter I Contradiction

1 Did Antisthenes claim that there is no such thing as contradiction? $\quad 29$

$2 \quad$ Was Antisthenes the first theoretician of the predicate? 30

3 Aristotle contra Antisthenes 31

4 A 'mad' contradictor 33

$5 \quad$ Antisthenes and ouden legein $\quad 35$

6 Aristotle's unconvincing rejoinder $\quad 36$

7 The silver-tin analogy 37

8 The Antistheneans $\quad 39$

$9 \quad$ Was makros logos an unusual notion? 41

10 The enumerative definition 43

1 Was the enumerative definition a trouvaille of the Antistheneans?

2 Does 'one cannot say what a thing is' conflict with Antisthenes' own view? $\quad 46$

11 Antisthenes' followers and teaching 48

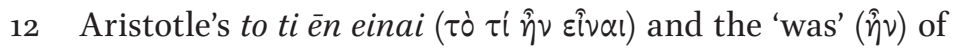
Antisthenes' explanation of logos

13 The imperfect tense in the logos formula, why not also a future tense? 
Chapter II Investigation of names 53

$1 \quad$ Name (onoma) 53

2 An example of the investigation of a name (polytropos) 54

3 The logos formula reconsidered $\quad 56$

4 Brancacci's solution to the imperfect $\hat{\nu} \nu \quad 59$

$5 \quad$ An interim assessment: Antisthenes contra Plato? 62

6 Reconsideration of the issue of contradiction (Plato's Euthydemus) 64

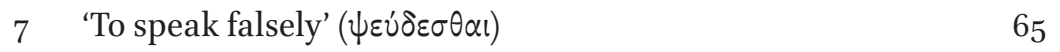

8 'Nearly' ( $\sigma \chi \varepsilon \delta \delta$ v) 67

9 Antisthenes' teaching practice $\quad 69$

10 Appendix I: Guthrie's systematic survey 71

\section{Part II Antisthenes' Views on theology:}

HIS THEORETICAL APPROACH TO THE STUDY OF HOMER

Chapter I Theology

1 Antisthenes and monotheism: was Antisthenes the first monotheist?

2 Aphrodite's case $\quad 78$

3 Pleasure as background to theological issues 80

4 Antisthenes and the popular gods $\quad 82$

Chapter II Antisthenes' scientific approach to the study of Homer 85

1 Polytropos $\quad 85$

1 Section $1 \quad 85$

2 Section 2 (lysis) $\quad 86$

$\begin{array}{lll}3 & \text { Section } 3 & 87\end{array}$

2 Commentary on the sections $\quad 88$

$1 \quad$ Strange section $3 \quad 88$

2 Antisthenes' logical style $\quad 89$

3 Argumentation in Section 2 91

4 Section 3 revisited $\quad 93$

3 Aristotle corrected 95

Chapter III Antisthenes' interpretation of other Homeric figures 97

1 A critical observation: Antisthenes in favour of Homer and the Cyclopes 


\section{Part III Antisthenean ethics}

$\begin{array}{ll}\text { Chapter I Ethics and myth } & 107\end{array}$

$1 \quad$ Introduction: moral strength 107

2 Heracles: ethics and paideia 108

3 Heracles and heavenly matters 109

4 Heracles and money 110

5 Heracles and virtue 111

6 Properties of virtue and wisdom (phronēsis) 112

$\begin{array}{lll}\text { Chapter II Sex, marriage, family } & 114\end{array}$

$1 \quad$ Antisthenes' teaching regarding sex and marriage 114

2 Adultery 115

3 Family 117

$\begin{array}{lll}\text { Chapter III Aspasia } & 119\end{array}$

1 Introduction $\quad 119$

2 Aspasia and Pericles $\quad 120$

3 Aspasia and Menexenus $\quad 122$

$\begin{array}{ll}\text { Chapter IV Alcibiades } & 125\end{array}$

$1 \quad$ Alcibiades and beauty $\quad 125$

2 Alcibiades' bad behaviour $\quad 126$

$\begin{array}{lll}\text { Chapter V Antisthenes and politics } & 128\end{array}$

1 Introduction $\quad 128$

$2 \quad$ Archelaus, the bad king? 129

3 Whence Antisthenes' preference for Cyrus as the good king? 132

4 Antisthenes' Cyrus works and Xenophon's Cyropaedia 134

5 Good and bad in the state 137

6 Social theory 139

$\begin{array}{ll}\text { Chapter VI The wise } & 140\end{array}$

1 The wise person $\quad 140$

2 The wise as models 141 
Chapter VII Antisthenes and Xenophon 143

1 Introduction 143

2 Jealousy and envy 143

3 Friendship 145

4 Friendship and 'orthosemantics' 147

Chapter VIII A portrait of Antisthenes in Xenophon's Symposium 149

$1 \quad$ Antisthenes in Xenophon's Symposium 149

2 The teachability of virtue $\quad 151$

3 Antisthenes as a cross-examiner $\quad 154$

4 Antisthenes and Niceratus on Homer $\quad 156$

5 Antisthenes' speech $\quad 158$

6 Pandering 164

$7 \quad$ Two incidental appearances $\quad 167$

8 The final scene between Socrates and Antisthenes $\quad 168$

9 Antisthenean themes in Xenophon's Symposium 172

Epilogue: Antisthenes, an assessment 174

Appendix II: The Speeches of Ajax and Odysseus $\quad 176$

$\begin{array}{ll}\text { Introduction } & 176\end{array}$

$\begin{array}{ll}\text { Antisthenes' sources } & 176\end{array}$

$\begin{array}{ll}\text { The aim of the speeches } & 178\end{array}$

Ajax's speech: 'Not words but deeds' 179

Odysseus' speech: 'I alone am the saviour of the Greeks by secret $\begin{array}{ll}\text { acts' } & 184\end{array}$

Antisthenes' book On Courage 190

$\begin{array}{lr}\text { Bibliography } & 192\end{array}$

Concordance Giannantoni (SSR) - Caizzi (D.C.) 195

$\begin{array}{ll}\text { Index } & 205\end{array}$

Index of fragments cited $\quad 205$

$\begin{array}{ll}\text { Index of passages cited } & 211\end{array}$

$\begin{array}{ll}\text { Index of names } & 216\end{array}$

Index of modern scholars $\quad 219$

Index of Greek words $\quad 220$ 


\section{Preface}

For most of his professional life, the author of the present book, P.A. (Piet) Meijer, was university lecturer in Ancient Philosophy in the Classics department of Leiden University where he taught with contagious enthusiasm. His classes were characterized by an attractive sort of irreverence towards academic authority. Any scholar, no matter how great his or her reputation, could be wrong and Meijer would take great pleasure in demonstrating that, in his view, they often were, on the basis of thoughtful and often innovative readings of the primary texts. In much the same spirit he meanwhile produced a steady stream of studies on a variety of subjects, such as Plotinus' metaphysics (Plotinus on the Good or the One (Enneads VI,g): An Analytical Commentary, Amsterdam 1992), Parmenidean ontology (Parmenides Beyond the Gates: The Divine Revelation on Being, Thinking and the Doxa, Amsterdam 1997) and Stoic theology (Stoic Theology: Proofs for the Existence of the Cosmic God and of the Traditional Gods, Delft 2007), to mention but the most important ones.

Upon his retirement, Meijer continued to do research with an almost youthful zeal. He had discovered Antisthenes, whose wit, intellectual acuity and subversive character had clearly struck a cord with him. As Meijer himself sets out in the introduction to this book, Antisthenes was one of the most important and colourful followers of Socrates. He made a major contribution to the history of ancient philosophy by offering the first definition of logos. Unfortunately, his reputation would soon be eclipsed by that other pupil of Socrates, Plato. As a result, Antisthenes' many books dropped out of circulation and hence did not survive. For the reconstruction of Antisthenes' views, then, we depend on reports of others, and those of Aristotle in particular. In the first part of this book, Meijer argues that Aristotle did not do justice to Antisthenes and sets out to offer a new, provocative interpretation of the famous logos doctrine of the latter. He argues that Antisthenes' famous oikeios logos is not a definition, as Aristotle had claimed, but an argument that teaches or clarifies what something was or is. One attractive aspect of Meijer's new understanding of Antisthenes' logos concept is that it allows him to connect this important aspect of Antisthenes' thought to another, that of the study of Homer. Thus, Meijer interprets Antisthenes' well-known discussion of the question why Homer calls Odysseus polytropos as an example of an Antisthenean oikeios logos: it clarifies the name of a figure from the (mythological) past. This is the topic of the second part of this book. The third part, finally, deals with the 
meagre remains of Antisthenes' ethics, including his views on sex, marriage, and adultery.

Meijer had virtually completed this comprehensive study of Antisthenes when, on 29 January 2010, he suffered a heavy stroke. He made a partial recovery, yet it gradually became clear that he would never again be in a position to see the manuscript through the press. It is at this point that his friends stepped in and made the present publication possible by generous donations of their time and energy. The initiative was taken by the unflagging Inge Aksoycan-de Bever, who made sure that everything that needed to be done was in fact done and found the book a home at Amsterdam University Press. Tony Foster, not for the first time, and Judith Deitch took it upon themselves to correct Meijer's English, once described by Meijer himself as 'an almost impossible task'. Peter Stork compiled the indexes, bibliographies, and concordances and made new translations of passages from Xenophon to replace outdated ones. If it had not been for them, this book would never have seen the light of day. Meijer is hugely thankful for their efforts and would here have expressed his gratitude to them himself, had he been able to do so.

R.M. van den Berg

Leiden, June 2016 


\section{Abbreviations}

BT

$C A G$

Caizzi

CB

CSEL

D.C.

DK

$D P h A$

Giannantoni

GCS

Guthrie III

Guthrie IV

Guthrie VI

LCL

$L G$

LSJ

OCT

PCG
Bibliotheca scriptorum graecorum et romanorum Teubneriana (Leipzig: B.G. Teubner)

Commentaria in Aristotelem graeca, 23 vols (Berlin: G. Reimer, 1882-1907)

see D.C.

Collection des Universités de France publiée sous le patronage de l'Association Guillaume Budé (Paris: Les Belles Lettres)

Corpus scriptorum ecclesiasticorum latinorum (Vienna: Verlag der Österreichische Akademie der Wissenschaften, 1866-)

Antisthenis fragmenta, ed. F.D. Caizzi (Milan/Varese: Istituto Editoriale Cisalpino, 1966)

Die Fragmente der Vorsokratiker, ed. H. Diels and W. Kranz, 3 vols (6th edn, Berlin: Weidmann, 1951-1952)

Dictionnaire des philosophes antiques, i:Abam(m)on à Axiothéa (Paris: Centre National de la Recherche Scientifique, 1989)

\section{see $S S R$}

Die Griechischen Christlichen Schriftsteller der ersten Jahrhunderte (Berlin: Akademie-Verlag, 1897-)

Guthrie, W.K.C., A History of Greek Philosophy, iii: The FifthCentury Enlightenment (Cambridge: Cambridge University Press, 1969)

Guthrie, W.K.C., A History of Greek Philosophy, iv: Plato, the Man and His Dialogues: Earlier Period (Cambridge: Cambridge University Press, 1975)

Guthrie, W.K.C., A History of Greek Philosophy, vi: Aristotle: an encounter (Cambridge: Cambridge University Press, 1981) The Loeb Classical Library (Cambridge, Mass. \& London: Harvard University Press)

Lexicographi graeci (Leipzig: B.G. Teubner)

A Greek-English Lexicon, ed. H.G. Liddell, R. Scott, H.S. Jones, R. McKenzie, gth edn (Oxford: Clarendon Press, 1968) Oxford Classical Texts (Oxford: Clarendon Press)

Poetae comici graeci, ed. R. Kassel and C. Austin (Berlin/ New York: de Gruyter, 1983-) 
PG

Patrologiae cursus completus, series Graeca, ed. J.-P. Migne (Paris, 1857-1866; reprint Turnhout: Brepols, 1959-1980)

$P L$ Patrologiae cursus completus, series Latina, ed. J.-P. Migne (Paris 1844-189o; reprint Turnhout: Brepols, 1956-1975)

$R h M$ Rheinisches Museum für Philologie (Frankfurt am Main: Sauerländer, 1842-)

SC Sources chrétiennes (Paris: Les Éditions du Cerf, 1941-)

SSR Socratis et Socraticorum reliquiae, ed. G. Giannantoni, 4 vols (Naples: Bibliopolis, 1990)

SVF Stoicorum veterum fragmenta, ed. H. von Arnim, 4 vols (Leipzig: B.G. Teubner, 1905-1924)

TAPhA Transactions and Proceedings of the American Philological Association (Boston: American Philological Association, 1869-)

VA

Antisthenes Atheniensis, in SSR

VB

Diogenes Sinopeus, in SSR 


\section{Primary sources - editions used}

Aesch., Pers.

Aesopus

Alex. Aphr., In Metaph.

Alex. Aphr., In Top.

Ammon., In Porph.

Anon. Lat. II

Aristid.

Arist., Metaph.

Arist., Pol.

Arist., Rhet.

Arist., Top.

Ars., Viol.

Artium scriptores
Aeschylus, 'Persae' in Aeschyli septem quae supersunt tragoediae, ed. D.L. Page, OCT (Oxford: Clarendon Press, 1972)

Aesopi fabulae, ed. E. Chambry, 2 vols, CB (Paris: Belles Lettres, 1925-1926)

AlexandriAphrodisiensis in Aristotelis Metaphysica commentaria, ed. M. Hayduck, CAG, 1 (Berlin: G. Reimer, 1891)

Alexandri Aphrodisiensis in Aristotelis topicorum libros octo commentaria, ed. M. Wallies, CAG, 2.2 (Berlin: G. Reimer, 1891)

Ammonius. In Porphyrii Isagogen sive V Voces, ed. A. Busse, CAG 4.3 (Berlin: G. Reimer, 1891)

'Anonymus II Arati epitomam isagogis et scholiis auctam continens', in Commentariorum in Aratum reliquiae, ed. E. Maass (Berlin: Weidmann, 1898) 99-306

Aelii Aristidis Smyrnaei quae supersunt omnia, ed. B. Keil, ii: Orationes XVII-LIII (Berlin: Weidmann,

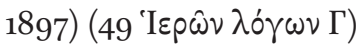

Aristotelis Metaphysica, ed. W. Jaeger, OCT (Oxford: Clarnedon Press, 1957)

Aristotelis Politica, ed. W.D. Ross, OCT (Oxford: Clarendon Press, 1957)

Aristotelis Ars Rhetorica, ed. W.D. Ross, OCT (Oxford: Clarendon Press, 1959)

Aristotelis Topica et Sophistici Elenchi, ed. W.D. Ross, OCT (Oxford: Clarendon Press, 1958)

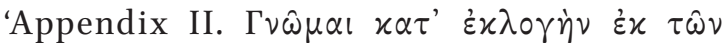

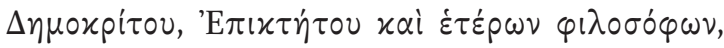

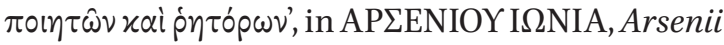
Violetum, ed. Chr. Walz (Stuttgart, 1832) 494-512 Artium scriptores (Reste der voraristotelischen Rhetorik), ed. L. Rademacher, Österreichische Akademie der Wissenschaften, Philosophischhistorische Klasse, Sitzungsberichte 227.3 (Wien: 1951) 
Ath.

Chrysipp.

Cic., N.D.

Cic., Ad Q. Fr.

Cic., Ad Att.

Clem. Alex., Strom.

Clem. Rom., Hom.

D. Chr.

D.L.

Epict., Diss.

[Eratosth.], Cat.

Eudocia, Viol.

Eus., $P E$
Athenaei Naucratitae Dipnosophistarum Libri $X V$, ed. G. Kaibel, 3 vols, BT (Leipzig: Teubner, 1887-1890)

Chrysippus Soleus: SVF 2.1-348; 3.1-205

M. Tullii Ciceronis scripta quae manserunt omnia, fasc. 45: De natura deorum, ed. O. Plasberg and W. Ax, BT (2nd edn, Stuttgart: Teubner, 1933)

M. Tulli Ciceronis Epistulae ad Quintum fratrem; Epistulae ad M. Brutum, ed. D.R. Shackleton Bailey, BT (Stuttgart: Teubner, 1988)

M. Tulli Ciceronis Epistulae ad Atticum, ed. D.R. Shackleton Bailey, 2 vols, BT (Stuttgart: Teubner, 1987)

Clemens Alexandrinus, i: Protrepticus und Paedagogus, ed. O. Stählin and U. Treu, 3rd edn, $G_{C S} 5^{2}$ (Berlin: Akademie Verlag,1972)

Clemens Alexandrinus, ii: Stromata Buch I-VI, ed. O. Stählin, L. Früchtel, and U. Treu, 4th edn, GCS $5^{2}$ (Berlin: Akademie Verlag, 1985)

Die Pseudoklementinen, i: Homilien, ed. B. Rehm, 3rd edn, ed. G. Strecker, GCS (Berlin:Akadamie Verlag, 1992; first edn, 1953)

Dionis Prusaensis quem vocant Chrysostomum quae exstant omnia, ed. J. von Arnim, 2 vols (Berlin: Weidmann,1893-1896 (Oratio 8: De virtute $=\mathrm{i}$, 95-102; Oratio13: De exilio = i, 179-189; Oratio 53: De Homero = ii, 109-113)

Diogenes Laertius. Lives of Eminent Philosophers, ed. T. Dorandi, Cambridge Classical Texts and Commentaries, 50 (Cambridge: Cambridge University Press, 2013)

Epicteti dissertationes ab Arriano digestae, ed. $\mathrm{H}$. Schenkl, BT (Leipzig: Teubner, 1916)

Pseudo-Eratosthenis Catasterismi, in Mythographi Graeci 3.1, ed. A. Olivieri, BT (Leipzig:Teubner, 1897) Eudociae Augustae Violarium, ed. J. Flach, BT (Leipzig: Teubner, 1880)

Eusebius Werke, viii: Die Praeparatio evangelica, ed. K. Mras, 2 vols, GCS 43.1-43.2 (Berlin, 1954-1956) 
Eust., Il.

Eust., Od.

Gell.

Gnom. Vat. 743

Hom., Il.

Hom., Od.

Isocr.

Lact., De ira Dei

Lact., Inst.

M. Aur., Med.

Ps.-Max.

Ps.-Max.

Min. Fel., Oct.
Eustathii archiepiscopi Thessalonicensis commentarii ad Homeri Iliadem, ed. M. van der Valk, 4 vols (Leiden: Brill, 1971-1987)

Eustathii archiepiscopi Thessalonicensis commentarii ad Homeri Odysseam, ed. G. Stallbaum, 2 vols (Leipzig, 1825-1826)

Aulus Gellius, Noctes Atticae, ed. P.K. Marshall, 2 vols , OCT (Oxford: Clarendon Press, 1968)

Gnomologium Vaticanum e codice Vaticano Graeco 743, ed. L. Sternbach, Texte und Kommentare, 2 (Berlin, 1963)

Sancti Eusebii Hieronymi Stridonensis Presbyteri opera omnia, ii: Adversus Jovinianum libri duo, PL 23 (1883) 221-354

Homeri opera, Ilias, ed. D.B. Monro, Th.W. Allen. 2 vols, 3rd edn, OCT (Oxford: Clarendon Press, 1920) Homeri opera, Odyssea, ed. Th.W. Allen. 2 vols, 2nd edn, OCT (Oxford: Clarendon Press, 1917-1920) Isocrate. Discours, ed G. Mathieu and É. Brémond, i, CB (Paris: Les Belles Lettres, 1929) [ Discours x: Helena $=$ i, 163-179]

L. Caeli Firmiani Lactanti opera omnia, ii.1: Libri de opificio dei et de ira dei, carmina, fragmenta, vetera de Lactantio testimonia, ed. S. Brandt, CSEL 27 (Prague; Vienna; Leipzig: 1893)

Lactantius. Divinarum Institutionum Libri septem, Fasc. i: Libri I et II, ed. E. Heck, A. Wlosok, BT (München/Leipzig: Teubner, 2005)

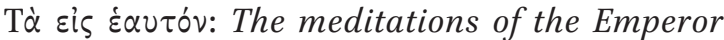
Marcus Aurelius, ed. A.S.L. Farquharson, i (Oxford: Clarendon Press, 1944)

MaximiAbbatis Capita Theologica scite Dicta atque Electa, ed. F. Combefis, PG 91: 721-1018 (Paris, 1865) S. Ihm, Ps.-Maximus Confessor. Erste kritische Edition einer Redaktion des sacro-profanen Florilegiums Loci Communes. (Stuttgart: Steiner, 2001) Minucius Felix. Octavius, ed. B. Kytzler, BT (Leipzig: Teubner, 1982) 
Olymp., In Alc.

Papyr. Flor.

Phld.

Phld.

Phot., Lex.

Pind., Nem.

Plato

Apol.

Euthd.

Gorg.

Hipp. Min.

Ion

Lg.

Lysis

$M x$.

Phd.

Prt.

$R p$.

Sph.

Symp.

Tht.
Olympiodorus. Commentary on the First Alcibiades of Plato, critical text and indices ed. L.G. Westerink (Amsterdam: North Holland, 1956)

Papyr. Flor. 113 post D. Comparetti, in Frammenti biografici da papiri, ed. I. Gallo, ii (Rome: Edizioni dell'Ateneo, 1980)

[Philodemus, De pietate] Philodem. Über Frömmigkeit, ed. Th. Gomperz, i: Abt.: Der Text, Herkulanische Studien, 2 (Leipzig, 1866)

[Philodemus, De pietate] Philodemus On Piety, i: Critical Text with Commentary, ed. D. Obbink (Oxford: Clarendon Press, 1996)

Photii Patriarchae Lexicon, ed. Chr. Theodoridis, 3 vols (Berlin/New York: de Gruyter, 1982-2013)

Pindarus, Nemea in Pindari carmina cum fragmentis, ed. B. Snell and H. Maehler, i, BT (5th edn, Leipzig: Teubner, 1971)

Platonis Opera, 5 vols, Oxford Classical Texts (Oxford: Clarendon Press):

Apologia, ed. E.A. Duke, W.F. Hicken, W.S.M. Nicoll, D.B. Robinson, and J.C.G. Strachan, in vol. 1 (1995)

Euthydemus, ed. J. Burnet, in vol. 3 (1903)

Gorgias, ed. J. Burnet, in vol. 3 (1903)

Hippias Minor, ed. J. Burnet, in vol. 3 (1903)

Ion, ed. J. Burnet, in vol. 3 (1903)

Leges, ed. J. Burnet, in vol. 5 (1907)

Lysis, ed. J. Burnet, in vol. 3 (1903)

Menexenus, ed. J. Burnet,in vol. 3 (1903)

Phaedo, ed. E.A. Duke, W.F. Hicken, W.S.M. Nicoll, D.B. Robinson, and J.C.G. Strachan, in vol. 1 (1995) Protagoras, ed. J. Burnet, in vol. 3 (1903)

[Respublica] Platonis Rempublicam, ed. S.R. Slings (2003)

Sophista, ed. E.A. Duke, W.F. Hicken, W.S.M. Nicoll, D.B. Robinson, and J.C.G. Strachan, in vol. 1 (1995) Symposium, ed. J. Burnet, in vol. 2 (1901)

Theaetetus, ed. E.A. Duke, W.F. Hicken, W.S.M. Nicoll, D.B. Robinson, and J.C.G. Strachan, in vol. 1 (1995) 
Plut., Per.

Porph., Ad Il.

Porph., Ad Od.

Procl., In Alc.

Procl., In Cra.

Schol. Hom.

Simp., In Cat.

Soph., Ajax

Stob., Anth.

Suda

Teleclides

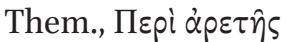

Thdrt., Graec. aff. cur.

Vita Pythagorae
Plutarchus, Vita Periclis, in Plutarchi Vitae Parallelae, ed. C.L. Lindskog and K. Ziegler, i.2, BT (2nd edn, Leipzig: Teubner, 1959)

Porphyrii Quaestionum Homericarum ad Iliadem pertinentium reliquias, ed. H. Schrader, 2 vols (Leipzig: Teubner, 1880-1882)

Porphyrii Quaestionum Homericarum ad Odysseam pertinentium reliquias, ed. H. Schrader (Leipzig: Teubner, 189o)

Proclus Diadochus. Commentary on the first Alcibiades of Plato, ed. L.G. Westerink (Amsterdam: North Holland, 1954)

Procli Diadochi in Platonis Cratylum commentaria, ed. G. Pasquali, BT (Leipzig: Teubner, 19o8)

Scholia in Homeri Iliadem, ed. I. Bekker, 2 vols (Berlin: G. Reimer, 1825-1827)

Scholia Graeca in Homeri Iliadem, ed. H. Erbse, 7 vols (Berlin: de Gruyter, 1969-1988)

Simplicii in Aristotelis categorias commentarium, ed. K. Kalbfleisch, CAG 8 (Berlin: Riemer, 1907)

Sophoclis Fabulae, ed. H. Lloyd-Jones and N.G. Wilson, OCT (Oxford: Clarendon Press, 1990)

Ioannis Stobaei Anthologium, ed. C. Wachsmuth and O. Hense, 5 vols (Berlin, 1884-1912)

Suidae Lexicon, ed. A. Adler, 5 vols, $L G 1$ (Leipzig: Teubner, 1928-1938)

in Poetae Comici Graecae, ed. R. Kassel and C. Austin, vii (Berlin/New York: de Gruyter, 1989)

Themistii Orationes quae supersunt, ed. H. Schenkl†, G. Downey, and A.F. Norman, iii, BT (Leipzig: Teubner, 1974)

J. Gildemeister and F. Bücheler, 'Themistios Пврі

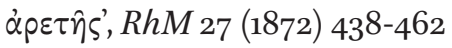

[Theodoretus, Graecarum Affectionum Curatio] Théodoret de Cyr. Thérapeutique des maladies helléniques, ed. P. Canivet, 2 vols, SC 57 (Paris: Les Éditions du Cerf, 1958)

in Porphyrii philosophi Platonici opuscula selecta, ed. A. Nauck, (Leipzig: Teubner, 1886; 2nd edn reprint, New York: Olms, 1977) 17-52 
Xenoph.

Xen.

Cyr.

Mem.

Symp.
Xenophanes 21, 1.113-139 in DK

Xenophontis opera omnia, ed. E.C. Marchant, 5 vols, Oxford Classical Texts (Oxford: Clarendon Press):

Cyropaedia, in vol. 4 (1910)

Memorablia, in vol. 2 (2nd edn, 1901)

Symposium, in vol. 2 (2nd edn, 1901) 


\section{Introduction $^{*}$}

Antisthenes, a follower of Socrates and a rival of Plato, did not like democracy very much. On one occasion, he ridiculed the practice of voting, advising the Athenians to elevate donkeys to horses by voting. The Athenians considered this advice, to say the least, foolish. However, Antisthenes explained it by adding further insult: 'But among you there are generals who have not learned anything but have been elevated to the rank of general only by voting'.

This anecdote shows that Antisthenes was a witty philosopher, an outspoken character, and a rude fellow who enjoyed surprising his interlocutors. When someone once remarked that many people praised him, he retorted: 'Why, what did I do wrong?'2 It is important to note his rudeness as well as his surprising reversals of established opinion because many fragments are marked as authentic precisely on account of these characteristics. These fragments often contain short, pithy statements that were very apt for quotation and in this way found their way into the tradition; but we shall see that he was also very capable of argument in a strictly philosophical manner. This study will also demonstrate that the pithy one-liners were

* The fragments of Antisthenes' work have been collected by F. Decleva Caizzi, Antisthenis Fragmenta, Milan 1966, Frammenti nos. 1-195, p. 17-74; Note ai Frammenti, p. 77-128 (D.C.) and by G. Giannantoni, Socratis et Socraticorum Reliquiae, Naples 1990, VA Antisthenes Atheniensis, nos. 1-208, II, 137-225 and Note 21-40, IV, 195-411 (SSR VA). Giannantoni provides an enormous amount of discussion of the scholarly literature and is required reading for every investigator, not only of Antisthenes' work but also of the other Socratics and Socrates himself. It is a pity that Giannantoni provides no collation with Caizzi's fragments because the older literature uses Caizzi's numbering, therefore for convenience's sake I have added a concordance (p. 195-204). Giannantoni's collection is more extensive than Caizzi's, and it is unfortunate that there is no discussion of the embedding of the extra fragments in his Note. There are occasions where 'new' fragments lacking the name of Antisthenes are added without convincing reasons, making these so-called fragments dubious; explanations based on this type of fragment are often not convincing either. Nevertheless, Giannantoni's great work is impressive, inescapable and indispensable. See also Goulet-Cazé 1989, 249-250, who adds some new parallels and passages. A recent collection of the fragments of Antisthenes is S.H. Prince, Antisthenes of Athens. Texts, translations and commentary 2015.

1 D.L. 6.8 (SSR VA 72; D.C. 169). Antisthenes wrote a series of political works (D.L. 6.16; see pp. 128-139). Here we may also observe Antisthenes' interest in learning, which will play a role in my discussion below.

2 D.L. 6.8 (SSR VA 89; D.C. 178C). 
often mitigated in his theoretical discussions or in further statements of his personal views. Such slogans, then, were meant to be provocative and to draw attention to his views, and this explains the imbalance in relation to Antisthenes' other utterances.

With regard to his historical reception, Antisthenes has suffered quite a run of bad luck. According to Popper, Antisthenes was the only worthy successor to Socrates, the last of the 'Great Generation'. Although his intellectual status in his own day was high, his social class was low: his father was a dealer in salt fish and his mother of non-Athenian descent, a Thracian by birth. ${ }^{4}$ The prominent rhetor Isocrates wrote twice against his rivals (Against the Sophists [13] and the Helena [10]), presumably at the opening of his school in 393 B.C. or just after that, ${ }^{5}$ and the first rival hinted at in the Helena is Antisthenes, ${ }^{6}$ ranked before Plato and others. It would seem that at that time Plato was less known or less important, perhaps still at the beginning of his philosophical career and not yet having developed his doctrine of the Ideas. ${ }^{7}$ Antisthenes was also eager to respond to Isocrates, which can be seen in three book titles, as listed by Diogenes Laertius, launched against Isocrates and Lysias. ${ }^{8}$ Thus, Antisthenes seems to have

3 Popper, The Open Society, 194; for other, less flattering judgements, see Guthrie III, 305; for my own judgement see pp. 174-175 below.

4 See p. 132-133 below about Antisthenes' parents.

5 Mikkola, Isokrates, 293, and Mathieu and Brémond, Isocrate, 160.

6 Isocrates, Helena [10], 1 (SSR VA 156; not in D.C.).

7 Plato's Academy started in 387 B.C. Some believe that Plato was included in the attack on Antisthenes in the Helena; see Giannantoni, Nota 27, IV, 274. Even so Antisthenes was more important than Plato because the description given does not fit the teaching of the young Plato, but is typical for Antisthenes (see for the contents of the attack below p. 34 and n. 16).

8 D.L. 6.15 (SSR VA 41.7-8; D.C. 1.7-8). Among these polemic writings we find a work entitled Against Isocrates' 'Without Witnesses'('Amartyros'). It is rather difficult to imagine what objections Antisthenes launched against this work of Isocrates. The text discussed the fact that Euthynus, a nephew of Nicias, refused to pay back the full sum of three talents which Nicias had given him in deposito 'without witnesses', restoring afterwards only two talents and saying he had received only two talents. It seems that a trivial thing such as the repayment of money was an object for polemics; but this appears to underestimate the issue. It became a cause célèbre, which involved not only Isocrates but also Lysias. Isocrates wrote an assisting work (a deuterologos) to function as a defence of his friend Nicias, who pressed charges against his cousin Euthynus (in 402 or 403 B.C.). Lysias' speech contained an attack on Nicias in favour of Euthynus. Isocrates' work was the target of Antisthenes' detailed criticism. Twenty years later, in 380 B.C., Isocrates complained that he and his work had been victims of many trivial criticisms, intending in his turn to criticize Antisthenes. Thus, we may conclude that Antisthenes' criticism touched Isocrates deeply since he returned to the issue after two decades had passed. See Patzer's thorough discussion of the entire issue in Antisthenes, 234-238. We may conclude that even in 380 B.C. Antisthenes still had a prominent place in the intellectual debates of the time. 
been - at least in the period after Socrates' death - an important intellectual figure. He would perhaps have become Socrates' most important and most famous disciple if he had not been overshadowed by the genius of Plato, a younger companion of Socrates. Antisthenes regarded Plato as his major rival and quarrelled with him because he felt that Plato had victimized him. Therefore he wrote a work with the rude title Sathōn, which means 'penis of a little boy', a parody of Platon, or perhaps suggested by the fact that Plato was also a nickname, meaning 'the broad one' because of his build or his forehead (cp. Greek $\pi \lambda \alpha \tau u$ s, 'broad'). ${ }^{9}$ Incidentally, Plato in his turn did not make any attempt to refute Antisthenes publicly under his name. Furthermore, Plato was not the only adversary Antisthenes introduced by a rude nickname; the above mentioned rhetors were also victims of Antisthenes' verbal jokes: Isographēs ('Plagiarizer') for Isocrates and Desias ('Arrester') for Lysias. ${ }^{10}$ The use of these nicknames is evidence that some titles as we know them from Diogenes Laertius' catalogue were given by Antisthenes himself and thus must be authentic.

9 Plato's real name was Aristocles (after his grandfather); see D.L. 3.4; Guthrie IV, 12, n. 1.

10 Plato is the only philosopher Antisthenes attacked by name according to the list of titles in Diogenes Laertius, albeit only by hinting at Plato through the nickname Sathōn (6.16; see also

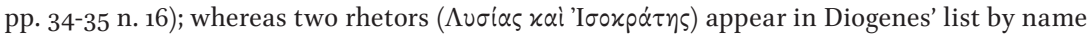
(D.L. 6.15). On the word $\Sigma \dot{\alpha} \theta \omega \nu$ see Caizzi, p. 99 on frs. 36-37, and Giannantoni, Nota 34, IV, 328, on VA 147-148. The meaning of the word is not quite clear. Caizzi refers to Phot., Lex. $\sigma 21$ s.v. $\sigma \dot{\theta} \theta \omega \nu$ (III, 335), who quotes Teleclides (F 71 PCG VII, 692) as saying that i $\pi 0 x o ́ p ı \sigma \mu \alpha \pi \alpha ı \delta i \omega \nu$

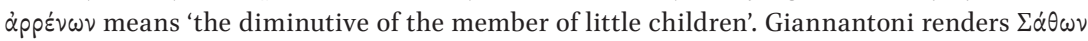
by minchione ('asshole'), an Italian word that can also have sexual implications. According to Patzer (Antisthenes, 232) it indicates Plato's sexual attitude ('spielt auf Platons Sexualverhalten an'). In any event, it is not meant to be a friendly word, hence the alienation of both Socratics. It appeared to be a rather rude habit of Antisthenes to sometimes introduce his adversaries under a nickname. The rhetors Lysias and Isocrates also appear under nicknames: Desias and Isographēs. Isographēs means Plagiarizer, as Patzer points out (Antisthenes, 228, 229): 'He who

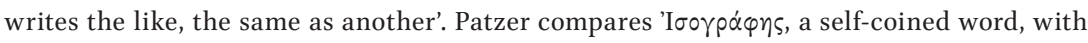
Timon's qualification of Plato $\tau \dot{\varepsilon} \tau \tau ı \xi ı ~ i \sigma o \gamma p \alpha ́ \varphi \circ$ ('writing like cicadas') in the sense of 'sweet

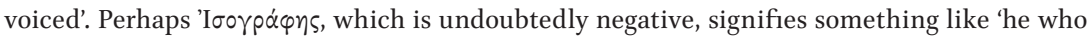
writes the same' (as himself), in the sense that he repeats himself, hence being far from being original, whereas Isocrates was proud precisely of his originality. Just like someone who is poly-graphos 'writes much', an iso-graphos 'writes the same'. In fact Isocrates actually repeats the reproaches against teaching rivals in the Helena that he had already launched in the Against the Sophists. Desias seems to mean 'Binder,' 'Arrester', a reversal of Lysias 'the Liberator': $\delta \varepsilon \dot{\varepsilon} \omega$ 'enchain' (in prison) is the opposite of to liberate ( $\left.\lambda v^{\varepsilon} \varepsilon \nu\right)$ which Antisthenes heard in the name Lysias. Lysias was a writer of pleas. Thus, to be named 'Arrester' is not a professional compliment for a barrister. We owe to Pohlenz the reconstruction of the title as read in the manuscripts (see SSR VA 41.34; D.C. 1.32), who was the first to recognize the names Desias and Isographēs in the MSS (see Patzer, Antisthenes, 221). Patzer has the best discussion of the whole issue, but see also Giannantoni, Nota 27, IV, 268-270. 
The work Sathōn dealt with the subject of contradiction, a highly interesting subject which will be discussed further. Antisthenes' book, with its degrading title bears silent witness to this animosity, and to the fact that he has been silenced by Plato's overwhelming influence. For from the numerous works of Antisthenes (more than 60 titles, some of which consisted of several scrolls!' $!^{11}$ virtually nothing remains, apart from two rather short speeches and a small cluster of fragments. Nevertheless, although reduced by history to the status of a minor philosopher, his thinking and views certainly merit further exploration.

\section{The importance of Antisthenes' philosophical views}

Antisthenes was the first in the history of philosophy to develop a definition for the word logos; in addition he was renowned for his theory about contradiction. Although the relation between monotheism and polytheism was not considered a problem in antiquity, he may also be considered the first Greek monotheist (however much he may have vacillated and despite not having any followers). That he was a philosopher in his own right, and not someone who simply depended on Socrates' thought or attempted to only memorialize Socrates' ideas, can be deduced from the fact that he wrote substantial books on a wide range of subjects, so also on subjects which were not the focus of Socrates' attention. Cicero regarded him as acutus, a 'shrewd' thinker, rather than eruditus, 'learned' (hominis acuti magis quam eruditi) and complimented him by stating that he enjoyed reading his work. ${ }^{12}$ Cicero must have had more of his texts than one, and therefore it is surprising that the wide range of Antisthenes' works and curiosity escaped his attention; otherwise he could not have referred to him as more shrewd than learned. As demonstrated above, his status in his own day was high.

Antisthenes seems to have had a powerful style and he was not averse to employing rhetorical means. He is reported to have used a pure Attic. ${ }^{13}$ It is debated whether his thoughts were presented in a direct manner or whether he used the dialogue form, which was highly popular and used

11 Timon the satirist called him a 'prolific babbler': D.L. 6.18 (SSR VA 41.75-76; D.C. 2 ).

12 Cic., Ad Att. 12.38.5 (SSR VA 84; D.C. 13). He complimented him by saying, 'I liked the Kyros (or Kyrsas) of Antisthenes just as I liked his other works' (mihi sic placuit, ut cetera Antisthenis). It could be that Cicero had only Antisthenes' political works in mind. Although in some MSS the name Kyrsas figures, I prefer 'Kyros' because of Cicero's interest in the person of Cyrus (see p. 134 below, and Giannantoni, Nota 31, IV, 295, esp. 298).

13 Patzer, Antisthenes, 98-101; about his style see also Rankin, Antisthenes, 151. 
almost exclusively by competitors such as Plato and Aeschines. In this connection we must stress that he was not averse to ad hominem polemics, as we saw with Isocrates and Lysias, and that the works involved can hardly have been dialogues. ${ }^{14}$ On the other hand, other works can be shown to have been dialogues.

It is difficult for us to establish whether Antisthenes was consistent in his thinking during this long life. It may well have gone through changes during his long writing career (approximately 445-365 B.C.). ${ }^{15}$ Although I view his ideas as being quite consistent and without noticeable changes, the limitations of what the tradition has left us makes it extremely difficult to trace changes - a problem that has not attracted attention in the scholarly literature.

While Antisthenes' contributions to ancient philosophy have been hotly debated in the past and have received ample attention recently, they are worthy of another review, for it is clear that both Plato and Aristotle have corrupted our perspective on Antisthenes' ideas on logos. ${ }^{16}$ In addition, his views on theology, especially in relation to Homer, are of interest in conjunction with his theoretical ideas and methods. Moreover, his views on ethics merit consideration. Therefore, this book is divided into three parts:

I Logos and predicate;

II Antisthenes' views on theology; his theoretical approach to the study of Homer;

III Antisthenean ethics.

14 Cp. D.L. 6.15, and Lysias, see p. 22 and n. 8 above.

15 Giannantoni, Nota 21, IV, 200.

16 See Giannantoni's notes in SSR IV, 195-411; also important is Brancacci, Oikeios logos (1990; French translation with the title Antisthène: Le discours propre, 2005). 